\title{
The impact of economic and social status on food choice
}

\author{
By John McKenzie, Food $\mathscr{F}^{\circ}$ Drink Research Limited, Mill House, 87 Shaftesbury \\ Avenue, London $W_{\mathrm{r}} V{ }_{7} A D$
}

\section{Fundamental considerations}

There are a number of fundamental factors related to our primary concern, nutrition and poverty, that have been considered implicitly in our discussions but which in my view need to be stated specifically. I say this because it is around these issues that concern and indeed policy should be centred.

Specifically I list the prime fundamentals below.

(a) To the individual, poverty is much more of a relative thing than it is absolute matter. Particularly in Western society, frustration with physical conditions and capacity to purchase particular items is primarily related to two issues: what an individual has now compared to what he used to have, and what an individual has now compared to what other people have. It is by these criteria that people decide whether or not they are poor and indeed whether they should complain. Moreover, it should be recognised that these concepts are much easier to measure than is poverty in absolute terms. And it means poverty is as much concerned with no longer being able to afford a telephone as it is with the quantity of meat consumed in any one week.

(b) In social terms poverty is seldom self-imposed but almost always real. Too often, calculations are done which suggest that if a family spent their money in a different way they could have adequate nutritional status and living conditions. But to give up food patterns they are used to (or even cigarettes or alcohol), whilst it would possibly remove physical deprivation, would not remove poverty in any social sense.

(c) Poverty is about individuals and their personal circumstances and not about averages. Too often we look at poverty in terms of the average position, but, just as technically in nutrition terms this does not remove concern about deviations from the mean, and in particular the lowest $10 \%$, so too it ignores personal issues that are the very essence of poverty.

(d) People choose food, not nutrients, and nutrition is as much about the former as the latter. We tend to forget the adage promulgated so succinctly by John Yudkin for so many years. But nowhere is it more relevant than in the context of a poverty debate. Even if we persuade people to adopt new patterns to maintain nutritional adequacy in time of hardship, if they cannot choose the foods they want, they will still rightly consider themselves to be poor: they will have been deprived.

(e) Short-term crises may well be of greater significance both socially and nutritionally than longer-term deprivation. This is an issue I return to in some depth later in this paper. 
If the above concepts are in any way acceptable, I would suggest that we may have taken far too complacent a view in our specific analysis of various at-risk groups in the papers and discussions furnished earlier. Certainly it is in the context of these concepts that I would like to undertake my review.

\section{Impact of economic choice on food choice}

There is an abundance of evidence in both developed and developing countries to demonstrate that food choice is related to income and that, generally speaking, richer people have a more adequate, varied and palatable diet. A few examples will suffice in the present context.

The National Food Survey Committee (1972) report for 1970 shows that there is a steady decline in the consumption of milk, meat and fruit as one goes down the social classes, with growth in consumption of bread and potatoes (Table I).

Table $\mathrm{I}$. Consumption of various foods by families in the UK related to weekly income 1970

\begin{tabular}{|c|c|c|c|c|c|c|c|}
\hline & \multicolumn{5}{|c|}{ Gross weekly income of head of household* } & \multirow[b]{2}{*}{ OAP } & \multirow[b]{2}{*}{ All } \\
\hline & A & B & $\mathrm{C}$ & $\mathrm{D}_{1}$ & $\mathrm{D}_{2}$ & & \\
\hline Liquid milk (pints) & $5 \cdot 28$ & 470 & $4 \cdot 39$ & $4 \cdot 10$ & $4 \cdot 49$ & $4 \cdot 87$ & $4 \cdot 63$ \\
\hline Meat $(o z)$ & $4 \pi \cdot 90$ & $40 \cdot 24$ & $3^{8 \cdot 73}$ & $37 \cdot 65$ & $39 \cdot 20$ & $41 \cdot 07$ & $39 \cdot 53$ \\
\hline Fruit (oz) & 44.84 & $31 \cdot 67$ & $25 \cdot 94$ & $22 \cdot 11$ & $27 \cdot 28$ & 30.41 & $30 \cdot 34$ \\
\hline Bread (oz) & $29 \cdot 84$ & $36 \cdot 5 I$ & $40 \cdot 97$ & 44.44 & $39 \cdot 55$ & $29 \cdot 17$ & $38 \cdot 11$ \\
\hline Potato (oz) & $39-33$ & $51 \cdot 12$ & 56.63 & 55.91 & $52 \cdot 42$ & $43 \cdot 17$ & $5 \pi \cdot 84$ \\
\hline
\end{tabular}

*A, $£_{45}$ or more; $B, £_{27}-£_{44} ; C, £_{14}-£_{27} ; D_{1}$, under $£_{3} I_{4}$ (earned); $D_{2}$, under $£_{14}$ (unearned).

$\mathrm{OAP}$, old-age pensioners.

From The National Food Survey Committee (1972).

On a world basis, a similar picture emerges if we look at the percentage of total energy intake derived from cereals, starchy roots and sugar. Thus $80 \%$ of the energy is derived in this way in the Far East region, $72 \%$ in the Near East and $74 \%$ in Africa, compared to only $63 \%$ in Europe, $48 \%$ in Oceania and $40 \%$ in North America; the figure for Latin America is $64 \%$ (Sukhatme, 196r).

Table 2. Amount of money spent weekly on food by families in the UK in different income groups, in absolute terms and as a percentage of total income

\begin{tabular}{|c|c|c|c|c|c|c|}
\hline \multirow[b]{2}{*}{$\begin{array}{l}\text { Amount } \\
\text { Absolute terms }\left(f_{0}\right)\end{array}$} & \multicolumn{5}{|c|}{ Total income per week } & \\
\hline & $\begin{array}{c}\text { Under } \oint_{30} 10 \\
3.09\end{array}$ & $\begin{array}{c}E_{1}{ }_{5}-\mathcal{E}_{20} \\
5.61\end{array}$ & $\begin{array}{c}\qquad 30-f, 35 \\
8.06\end{array}$ & $\begin{array}{c}£ 50-f 60 \\
10.58\end{array}$ & $\begin{array}{l}680+ \\
14.61\end{array}$ & $\begin{array}{l}\text { Al1 } \\
8 \cdot 72\end{array}$ \\
\hline Percentage of total income & 33 & 30 & 27 & 25 & 20 & 25 \\
\hline
\end{tabular}

From the Family Expenditure Survey (1972).

Again, as is shown in Table 2, in the UK the total amount of money spent on food increases in line with the increase in the total amount of income entering the 
household. However, at the same time, as is equally shown in this and Table 3 , the percentage of total income being spent on food declines with a rise in income. A similar situation is true for the percentage of income going on housing, but as people get richer they spend more on clothing, transport and vehicles, and services. (Family Expenditure Survey, 1972).

Table 3. Percentage of total expenditure on various commodities or services by families in the $U K$ in different income groups

\begin{tabular}{|c|c|c|c|c|c|c|}
\hline \multirow[b]{2}{*}{ Item } & \multicolumn{5}{|c|}{ Total income per week } & \\
\hline & Under $£$ ro & $£=5-E_{20}$ & $f_{3} 0-f_{35}$ & $f, 50-6,60$ & $£ 80+$ & All \\
\hline Housing & 22 & I8 & 15 & I I & 10 & $\times 3$ \\
\hline Food & 33 & 30 & 27 & 25 & 20 & 25 \\
\hline Clothing & 5 & 7 & 8 & 9 & 10 & 9 \\
\hline Transport and vehicles & 3 & 6 & 12 & 17 & 18 & 14 \\
\hline Services & 8 & 9 & 8 & 9 & I5 & 10 \\
\hline
\end{tabular}

From the Family Expenditure Survey (1972).

All in all, the changing diet resulting from higher income is reflected in improved nutritional status. Thus the National Food Survey Committee (1972) report again shows that nutritional intake as a percentage of recommended intake is higher for almost all nutrients amongst the better-off social classes (Table 4).

Table 4. Nutrient intake of families in the $U K$, as a percentage of recommended intake, related to total income

\begin{tabular}{|c|c|c|c|c|c|c|c|}
\hline \multirow[b]{2}{*}{ Nutrient } & \multicolumn{5}{|c|}{ Gross weekly income of head of household* } & \multirow[b]{2}{*}{ OAP } & \multirow[b]{2}{*}{ All } \\
\hline & A & $\mathrm{B}$ & $\mathrm{C}$ & $\mathrm{D}_{1}$ & $\mathrm{D}_{2}$ & & \\
\hline Energy & I Io & I IO & 109 & 106 & 108 & 122 & III \\
\hline Protein & 132 & 127 & 124 & 124 & 125 & 136 & I 28 \\
\hline Calcium & 207 & 194 & 189 & 176 & 182 & 204 & I94 \\
\hline Iron & 125 & 124 & 124 & I 18 & I 13 & 124 & 124 \\
\hline Thiamin & 124 & 123 & 122 & 118 & 121 & 133 & I 24 \\
\hline Vitamin $\mathrm{C}$ & $23 I$ & 192 & 172 & 158 & 165 & I 54 & 184 \\
\hline Vitamin D & 80 & 89 & 87 & $8 \pi$ & 83 & IIO & 84 \\
\hline
\end{tabular}

*A, $£_{45}$ or more; $\mathrm{B}, £_{27}-£_{44} ; \mathrm{C}, £_{14} £_{27} ; \mathrm{D}_{1}$, under $£_{14}$ (earned); $\mathrm{D}_{2}$, under $£_{1} \mathrm{I}_{4}$ (unearned). OAP, old-age pensioners.

From The National Food Survey Committee (1972).

However, it would of course be wrong to argue that prosperity creates no problems in terms of diet and food choice. Problems emerge on two fronts. On the one hand it can produce the 'self-induced' diseases of affluence such as obesity, heart disease and diabetes. On the other hand some 'prestige foods' of affluence may be singularly less desirable than the alternatives consumed by the poor; here I am thinking of such products as unfortified white flour, carbonated soft drinks and even such Eastern delicacies as bird's nest soup. 


\section{The impact of social status on food choice}

The role of income in choice is almost too deceptively obvious and significant, but the social and psychological roles are much more complex. Fundamentally we deal with choice at two levels. Imagine a table: on it are placed all the foods which we can afford (or alternatively which we could afford if we spent all our available money on them). This is the level of imposed economic choice. But then from this wide range of available foods (or indeed brands) we make a selection of those which we wish to eat. This is based on sociological and psychological criteria. Again, given that from the foods available on the table it would be easily possible to choose a nutritionally adequate diet, it very much becomes the sociological and psychological criteria that determine whether our diet is good or bad.

Below I list five essential criteria of a sociological-psychological nature which influence this choice.

(a) Food as an aid to security. A great deal of our choice of food is to provide reassurance when we feel insecure or uncertain. Frequently security means retaining past habits and not trying anything new or in any sense different. When everything else is going wrong, our ability to gain comfort from a standard diet is well recognised. Partially at least this reflects our need psychologically to demonstrate consistently that now, when we no longer directly provide for ourselves by hunting for or growing food, it is still readily available to satisfy our every requirement. But it may be more than this. Old people, for example, tend to store up food: their larders will contain many more packets of tea or tinned fruit than the average, a clear demonstration about their fears both of a practical, physical and an emotional nature for the future.

(b) Food selection and preparation as a substitute for maternal creativity. As women become liberated and lose many of the traditional means of demonstrating their creativity and the quality of their performance as a homemaker (in particular by not now having a continuous child-bearing and rearing role of 25 years or more), they increasingly turn to food as a new indicator of their talent. By budgeting well, shopping well, cooking well, they implicitly or explicitly seek to show their creativity and to earn praise from the family.

(c) Food choice as a means of demonstrating group acceptance, conformity, prestige. Because everyone is aware of food and it has such a prominant position in our life, we demonstrate by our selection our attitude to society (whether we seek acceptance by it or wish to rebel from it) and the image we want to project of ourselves. Dry versus sweet sherry, instant versus ground coffee, how we eat our peas (and whether they are fresh, frozen or tinned), whether we use a fork with our dessert, would be just a very few examples of how such criteria may work.

(d) Food as a means of demonstrating mood and personality. Not only do we use food to portray to the outside world a celebration (champagne and more exotic foods) or special occasion (Christmas turkey, birthday chicken, Sunday lunch beef), but also we project our personality and our reactions to certain circumstances. Thus, for example, second children often reject a basic food or drink (in particular tea or 
coffee) to assert their individuality and we all, if we are excited or in a temper, may find it extremely difficult to eat at all.

(e) Food as a compensation for denial or during times of crisis. At both the extremes of food intake there is often a psychological condition reflecting an unhappy marriage, death, boredom, frustration, inability to cope with a particular situation or the world at large, etc. Cure the emotional situation and you can usually make people eat again or cut back on their intake.

In this way we form a set of food habits. They make for almost a unique formula for each individual, although of course they often only differ in minimal ways from our peer groups. Yet these minimal variants resulting from social and psychological implications can well affect the total food intake and the nutritional status of individuals.

\section{The problem of the short-term crisis}

The problem of the short-term crisis has been viewed in a number of different ways in this symposium. Thus Dr Land has identified a particular vulnerable group to be those on the edge of poverty, for whom marginal changes in income or mistakes in how they spend it can create a real problem situation. Dr Cohen has identified two problems amongst the elderly which require financial readjustment: when they stop work and have to live on a pension, and when the savings run out. In discussion, Dr Whitehead has identified a large proportion of Ugandans who live in what we might call a nutritional danger zone but who only 'drop over the edge' into malnutrition in bad times. A major part of my own thesis is that poverty and food choice is in itself of particular concern when it emerges in the context of a short-term crisis, usually a reduction in income due to illness, unemployment or old age.

Let me examine how people react to this situation. Basically, when faced with a smaller income in an emergency or as a result of some change in their circumstances, respondents tend to cut back on food and drink rather than on other items of expenditure. This is simply because items such as the rent or mortgage, electricity and gas, even car hire-purchase payments, are rigid items which it is difficult to modify. But it is quite possible to change the amount of money one spends on food quite rapidly whether it is as a result of one of the crises outlined above or simply because one has overspent on something else this week.

A second feature at this time is that when the individual does cut back on food he does not necessarily cut back in a way which is nutritionally most desirable. Rather he cuts back on foods which are of less emotional significance to him. This was shown in a study of the workers in Dukinfield as long ago as the I840's. Their diet was measured during a period of prosperity in 1836 and during a period of relative hardship during $\mathrm{i} 8 \mathrm{4} \mathrm{I}$. In the latter period respondents cut back dramatically in their consumption of potatoes and meat (down $69 \%$ ), less so in that of butter (down $52 \%$ ), and much less in that of bread (down $29 \%$ ) and tea (down $36 \%$ ) (McKenzie, I966).

But whatever the changes which occur in diet at these times and whether or not they have any nutritional effect, it may be argued that they do carry important 
psychological significance. As I have tried to demonstrate throughout my paper, food consumption is undertaken for much more than nutritional purposes: it adds to emotional stability. If, at a time of dire crisis, families are forced to alter their food intake this adds to their instability at a most vulnerable time and should be avoided at all possible costs.

Unfortunately these short-term crises not only are much more likely to occur amongst the old and the poor, but equally these specific groups are much less likely to be able to cope with the situation. This can be explained by the following reasons:

(a) The poor tend to use money as an aid against intolerable conditions in which they live. Thus whether it is a visit to the Batley Variety Club, a pub down the road, or simply eating out with some friends, it reflects a situation in which they buy relief. Conversely they seldom socially eat or entertain in their own homes. Thus, a reduction in money removes this 'relief element' in their income.

(b) The old and the poor are less flexible in their attitude to foods and meal patterns. The lower social classes are more conservative in their attitude to life and both they and the old are less intellectually able to comprehend, absorb and find acceptable recommended changes in food patterns. In general, they are much more insecure about anything which creates a change in their life. As such, the short-term crisis hits them worse.

(c) As was shown early in this paper, the proportion of income going on fixed items such as rent and food is much greater amongst the poor. Thus they have less room to manoeuvre when their income is suddenly reduced.

(d) Commercially it has been recognised for a long while that the poorer sections of the community are less efficient shoppers. The 'Which' type of document is very much aimed at and appeals to the middle class. The old and poorer are less able shoppers because they are more influenced by advertising; they are much more likely to purchase the leading brand than the Sainsbury or Tesco variety which is 2p cheaper; they have less time and are less good at bargain hunting; they have more problems in persuading their family to adapt to some new method.

Thus my argument is that short-term crises not only obviously come more frequently in the life of the poor and the elderly and affect a much larger proportion of the population than those who live directly in absolute poverty, but also come to groups of the population who are emotionally ill-equipped to deal with the crises.

In relief terms the implications are clear: one needs to support individuals financially to the level of their previous standard of living rather than compared to some absolute basic standard. Equally, one has to be careful in the short term to ensure that the money made available actually goes on the provision of an adequate diet: this at least might be one of the few positive merits about a payment in kind procedure.

\section{Conclusions}

If it is recognised that short-term poverty is of major significance, then we really have to gear our research programme in a totally different way. By this I mean 
we need to watch people over some time to measure both the nutritional and psychological effects resulting from changes in their income. And we need to measure them at the appropriate times. Thus we should not just observe old age pensioners, but people before they retire, when they have been retired for a year and later when their savings run out. Equally, we should observe people who are sometimes employed but who have a significantly greater chance of being unemployed within the next 3-year period. Again, both in nutritional and psychological terms, we need to watch individuals who represent a below-average position within the community. And we need to measure their desires and attitudes as much as their physical wellbeing.

The implication of all this to me is twofold. First, to return to an old hobbyhorse of mine, it is abundantly clear that our research must involve both the nutritionist and clinician, and the social scientist. Many of the apparently different conclusions we come to at present reflect a total lack of understanding and collaboration between the clinical and scientific disciplines on the one hand and the social scientist on the other. We really do need to co-operate and co-ordinate our activities.

Secondly, we have to recognise that in the sort of society in which we live almost everyone is going to suffer at least some of the short-term crises resulting from illness, unemployment and old age. Whilst these conditions may have little effect on over-all health status, they are emotionally of considerable significance. As such they merit further exploration.

Our Chairman began by commenting that politicians often seem little interested in the nutritional state of the community provided an adequate level was being achieved by the majority of the electorate. But one of the key things about the sort of arguments $I$ have been presenting is that whether or not poverty results in diets which are nutritionally unsatisfactory, certainly these diets are totally unsatisfactory in social terms to the consumer. Such social discontent is not only enormous but can have powerful political impact. Perhaps this is the way to the heart of the politician!

\section{REFERENCES}

Family Expenditure Survey (1972). Report for 1971. London: H.M. Stationery Office.

McKenzie, J. C. (I966). Past Dietary Trends as an Aid to Prediction, in Our Changing Fare [T, C. Barker, J. C. McKenzie and J. Yudkin, editors]. London: MacGibbon and Kee.

National Food Survey Committee (1972). Domestic Food Consumption and Expenditure: 1970. London: H.M. Stationery Office.

Sukhatme, P. V. (1961). $\mathscr{J l} R$. statist. Soc. 124, 477. 